\title{
Penerapan Metode Analytical Hierarchy Process (AHP) Sebagai Pendukung Keputusan dalam Menentukan Internet Service Provider Terbaik di Pangkalpinang
}

\author{
Yogi Prihartono \\ Program Studi Sistem Informasi \\ STMIK Atma Luhur \\ Pangkalpinang \\ yoggyprihartono@gmail.com
}

\author{
Hilyah Magdalena \\ Program Studi Sistem Informasi \\ STMIK Atma Luhur \\ Pangkalpinang \\ hilyah@atmaluhur.ac.id
}

\begin{abstract}
Internet service provider used in today's rapidly growing with a wide selection of advantages and disadvantages. Because it was so many criteria - criteria that can be used as a basic internet service providers the most suitable to be applied in the agency in Pangkalpinang. In this study, the authors raise some of the network providers are XL, Telkomsel, Indosat, Three and Smartfren. To select an Internet service provider with a six-level criteria. The level 1 criteria: ease of users, ease of use, speed of data transfer, type of service, access restrictions internrt / quota, network level, and the type of card, level 2 criteria consists of 20 criteria derived from special advantages to the internet service provider. As for the level 3 there are five alternatives are XL, Telkomsel, Indosat, Three and Smartfren. The results of this election result as an internet service provider $\mathrm{XL}$ is best as compared with Telkomsel, Indosat, Three, and Smaertfren. XL reliability levels reached $31.7 \%$. And the most influential factor in the selection process is the data transfer speed factor reached $32.5 \%$.
\end{abstract}

Keywords-Internet Service Provider, Pangkalpinang, Analitical Hierarchy Process, Expert Choice2000.

\section{PENDAHULUAN}

\section{A. Latar Belakang}

Saat ISP (Internet Service Provider) yang dalam istilah Indonesia adalah Penyedia Jasa Internet, yakni suatu lembaga atau perusahaan yang menghubungkan komputer pengguna dengan internet. Kebanyakan operator telekomunikasi adalah ISP. Perkembangan teknologi informasi yang semakin hari semakin meningkat, membuat aspek yang cukup besar dalam seluruh aspek kehidupan dan membawa manusia kedalam era globalisai, dimana pada era ini manusia memerlukan informasi yang terbaru (up to date) dengan cepat, praktis, efisien.

Pada umumnya internet merupakan salah satu teknologi yang sangat pesat perkembangannya dan sudah merupakan simbol dari cara berkomunikasi secara bebas, tanpa dibatasi ruang, jarak dan waktu. Dengan ditunjang oleh kelebihan yang dimiliki oleh internet, diantaranya bisa koneksi yang relatif terjangkau dan ketersediaan informasi yang tidak terbatas, internet kini menjadi alternatif utama untuk memenuhi segala kebutuhan terutama kebutuhan akan informasi dan pendidikan yang akan memberi nilai positif untuk semua aktifitas.

Namun demikian sudah banyak layanan internet yang bisa digunakan untuk membantu memudahkan pengguna dalam mengakses internet. Banyak kemudahan dan kelebihan yang mereka tawarkan. Layanan internet itu sendiri adalah hubungan antar berbagai jenis komputer dan jaringan di dunia yang berbeda sistem operasi maupun aplikasinya dimana hubungan tersebut memanfaatkan kemajuan media komunikasi (telepondan satelit) yang menggunakan protokol standar dalam berkomunikasi yaitu protokol TCP/IP yang berisikan informasi.

Sekarang ini sudah banyak paket internet yang disediakan oleh perusahaan telekomunikasi terutama di Pangkalpinang, diantaranya ada XL (Internet HotRot 3G+), Telkomsel (Telkomsel Flash), Indosat IM3 (Indosat Super 3G+), Three (Kuota ++) dan adanya Smartfren (Connex EVDO). Diantara kelima pilihan tersebut tentunya memiliki kelebihan dan kekurangan masing-masing serta pilihan tersendiri.

Tersedianya paket internet tentunya memiliki manfaat bagi pengguna internet khususnya bagi loket agency pospay PT. Pos Indonesia. Manfaat tersebut dapat berupa memperoleh kebebasan pengguna dalam mengakses internet dan aplikasi pospay dimanapun dan kapanpun serta biaya yang terjangkau tentunya.

Disini penulis akan membantu pengguna khususnya loket agency pospay untuk memberikan kemudahan serta alternatif dalam menentukan pilihan yang tepat dalam memilih paket internet. Diawali dengan munculnya Internet Service Provider yang menyediakan akses ke Internet 
dengan bandwidth berkisar antara $14.4 \mathrm{kbps}$ hingga 28.8 kbps. APJII sudah menginjak angka 155 ISP. Bisnis ISP memilik prospek yang bagus. Saat ini semua bisnis yang berbasis Internet tidak akan berkembang apabila infastruktur dan koneksi ke Internet tidak dibangun terlebih dahulu.

Ada beberapa provider jaringan yang dapat dijadikan pilihan untuk penggunaan internet di Pangkalpinang, yaitu : XL, Telkomsel, IM3, Three dan Smartfren. Kelima alternatif jaringan internet tersebut masing - masing mempunyai kekuatan dan kelemahannya. Agar pengembangan jaringan internet maka proses pemilihan provider yang tepat menjadi penting. Oleh karena itu penulis menggunakan AHP untuk mendukung pengambilan keputusan dalam pemilihan internet service provider mana yang terbaik di Pangkalpinang.

\section{B. Masalah Penelitian}

Pada awalnya jumlah pengguna internet bertambah didorong oleh kemudahan telekomunikasi. Kemudian para pengguna sadar bahwa mereka tidak mungkin meninggalkan gaya hidup internet, karena sudah menjadi bagian dari komunitas virtual yang sesuai minatnya. Artinya jumlah pengguna internet tidak akan berkurang, melainkan akan terus bertambah. Hal ini yang membuat perusahaan jasa internet harus memanfaatkan teknologi informasi yang semakin berkembang pesat untuk meningkatkan kemampuannya dalam menghadapi persaingan dan mampu memberikan pelayanan yang memuaskan bagi pelanggan. Penting sekali bagi perusahaan ISP untuk memperhatikan keinginan pelanggannya.

Pada bidang bisnis Internet Service Provider (ISP) dimana tingkat dan dinamika persaingan antar Internet Service Provider (ISP) mulai tinggi. Setiap Internet Service Provider (ISP) berusaha menjadi yang terbaik dan menjaring pelanggan sebanyak - banyaknya dengan memberikan pelayanan yang memuaskan serta kemudahan bagi para pelanggan.

\section{Rumusan Masalah}

Berdasarkan identifikasi masalah di atas, maka dirumuskan permasalahan yang nantinya akan diuraikan solusinya hanya dua poin saja dari empat poin yang ada dalam pembatasan masalah, yaitu :

1. Faktor - faktor apa saja yang jadi pertimbangan dalam memilih Internet service provider?

2. Manakah internet service provider yang paling handal diantara XL, Telkomsel, IM3, Three dan Smartfren?

\section{Ruang Lingkup Penelitian}

Pembatasan masalah dalam penelitian ini sebagai berikut:
1) Faktor - faktor apa saja yang jadi pertimbangan dalam memilih Internet service provider?

2) Manakah internet service provider yang paling handal diantara XL, Telkomsel, IM3, Three dan Smartfren?

3) Metode pengambilan data diperoleh dengan menggunakan kuesioner.

4) Menggunakan AHP dalam memilih internet service provider untuk aplikasi agency postpay.

\section{E. Tujuan Penelitian}

Tujuan Penelitian ini adalah :

1) Melakukan kajian strategis dan evaluasi untuk memilih internet service provider untuk aplikasi postpay yang sesuai dengan kebutuhan loket agency.

2) Mengetahui tingkat kehandalan jaringan tersebut yang sesuai dengan kriteria dan sub criteria dengan teknik pendekatan berdasarkan AHP (Analytical Hierarchy Process).

\section{F. Manfaat Penelitian}

Penulis berharap penelitian ini dapat menyumbangkan manfaat untuk berbagai kalangan, baik di lingkungan akademik STMIK ATMA LUHUR sendiri, ataupun masyarakat luas pengguna ilmu pengetahuan. Berikut beberapa manfaat penelitian ini :

1) Setelah mengetahui kriteria - kriteria pemilihan Internet Service Provider untuk aplikasi loket agency pospay, maka akan menunjang pengambilan keputusan memilih provider dan paket internet yang tepat.

2) Bagi institusi, penelitian ini dapat digunakan untuk penelitian lanjut dalam penerapan aplikasi agency pospay sesuai dengan hasil pemilihan internet service provider dengan AHP.

Bagi penulis, penelitian ini merupakan sarana mengembangkan keilmuan, khususnya keilmuan dalam bidang metodologi penelitian

\section{TINJAUAN PUSTAKA}

Dalam penelitian ini penulis menggunakan beberapa tinjauan pustaka yang berkaitan dengan Sistem Pendukung Keputusan, Analytical Hierarchy Process, dan Internet Service Provider.

\section{A. Sistem Pendukung Keputusan}

Konsep Sistem Pendukung Keputusan (SPK) / Decision Support System (DSS) pertama kali diungkapkan pada awal tahun 1970-an oleh Michael S. Scott Morton dengan istilah Management Decision System. Sistem tersebut adalah suatu system yang berbasis komputer yang ditujukan untuk membantu pengambil keputusan dengan memanfaatkan data dan model tertentu untuk memecahkan berbagai persoalan 
yang tidak terstruktur.

Istilah SPK mengacu pada suatu system yang memanfaatkan dukungan komputer dalam proses pengambilan keputusan. Untuk memberikan pengertian yang lebih mendalam, akan diuraikan beberapa difinisi mengenai SPK yang dikembangkan oleh beberapa ahli, diantaranya oleh Man dan Watson yang memberikan definisi sebagai berikut, SPK merupakan suatu system yang interaktif, yang membantu pengambil keputusan melalui penggunaan data dan model-model keputusan untuk memecahkan masalah yang sifatnya semi terstruktur maupun yang tidak terstruktur.

Dalam sebuah Sistem Pendukung Keputusan tentunya kita perlu melakukanpengambilan keputusan. Namun kita tidak bisa begitu saja mengambil suatu keputusan. Perlu adanya suatu proses - proses yang harus dilalui untuk mengambil suatu keputusan. Dalam pengambilan keputusan pada Sistem Pendukung Keputusan ini juga melalui proses, dalam proses pengambilan keputusan tersebut mempunyai fase - fase dan model - model.

Sistem Pendukung Keputusan menggunakan konsep keputusan terprogram dan tidak terprogram dengan phase pengambilan keputusan yang merefleksikan terhadap pemikisan Decision Support Systems (DSS) saat ini. Konsep Sistem Pendukung Keputusan (SPK) atau Decision Support System (DSS) pertama kali diungkapkan pada awal tahun 1970-an oleh Michael S.Scott Morton dengan istilah Management Decision System. Sistem tersebut adalah suatu sistem yang berbasis komputer yang ditujukan untuk membantu pengambil keputusan dengan memanfaatkan data dan model tertentu untuk memecahkan berbagai persoalan yang tidak terstruktur dan semi terstruktur. DSS dirancang untuk menunjang seluruh tahapan pembuatan keputusan, yang dimulai dari tahapan mengidentifikasi masalah, memilih data yang relevan, menentukan pendekatan yang digunakan dalam proses pembuatan keputusan sampai pada kegiatan mengevaluasi pemilihan alternatif.

Proses pengambilan keputusan meliputi tiga tahap utama yaitu inteligensi, desain, dan pilihan. Kemudian menambahkan tahap keempat yakini implementasi [6]. Keempat tahapan pengambilan keputusan sebagai berikut:

1) Tahap Intelegensi

Fase ini dimulai dengan mengidentifikasi masalah yang ada dan mendefinisikan masalah tersebut secara eksplisit kemudian klasifikasi masalah tersebut dengan menempatkannya dalam suatu kategori yang dapat didefinisikan serta distrukturisasi masalah tersebut menjadi masalah terprogram dengany yang tidak terprogram, selanjutnya dekomposisikan masalah tersebut menjadi banyak sub masalah yang lebih sederhana kemudian definisikan kepemilikan masalah tersebut dan diakhiri dengan pernyataan masalah secara formal.

2) Tahap Desain

Tahap ini merupakan proses penemuan atau mengembangkan dan menganalisis tindakan yang mungkin untuk dilakukan. Hal ini meliputi pemahaman terhadap masalah dan menguji solusi yang layak. Dan pada fase ini dikembangkan sebuah model masalah pengambilan keputusan untuk dikonstruksi, dites dan divalidasi.

3) Tahap Pilihan

Tahap pilihan adalah tahap dimana dibuat suatu keputusan yang nyata dan diambil suatu komitmen untuk mengikuti suatu tindakan tertentu. Tahap pilihan meliputi pencarian, evaluasi, dan rekomendasi terhadap suatu solusi yang tepat untuk model. Sebuah solusi untuk model adalah sekumpulan nilai spesifik untuk variabel-variabel keputusan dalam suatu alternatif yang telah dipilih.

4) Tahap Implementasi

Tahap implementasi merupakan tahapan untuk merealisasikan alternatif solusi yang telah dipilih pada tahap sebelumnya untuk mencapai target yang diinginkan. Implementasi berarti membuat suatu solusi yang direkomendasikan bias berkerja untuk mengatasi masalah.

Penulis menggunakan AHP sebagai model pengambilan keputusan dengan software pendukungnya adalah Expert Choice 2000.

\section{B. Analytical Hierarchy Process}

Dalam industri manufaktur maupun jasa, pengambil keputusan sering kali dihadapkan suatu permasalah yang kompleks. Salah satu permasalahan yang tersebut adalah masalah menentukan pilihan dari beberapa kandidat atau sekadar mengurutkan prioritas dari beberapa kandidat. Contoh-contoh dalam industry manufaktur termasuk pemilihan supplier, pemilihan pembelian mesin, pemilihan lokasi pabrik, dan lain-lain. Sedangkan contoh-contoh dalam industry jasa seperti pemilihan kendaraan logistik, pemilihan pekerjaan konsultan, pemilihan rute pelayanan, dan-lain.

Permasalahan pengambilan keputusan dapat menjadi kompleks karena adanya pelibatan beberapa tujuan maupun kriteria. Salah satu tool (alat bantu) yang cocok digunakan untuk pemilihan kandidat atau pengurutan prioritas adalah Analytic Hierarchy Process (AHP) yang dikembangkan [5]. Secara spesifik, AHP cocok digunakan untuk permasalahaan pemilihan kandidat ataupun pengurutan prioritas yang memiliki sifatsifat sebagai berikut [3]:

1) Melibatkan kriteria-kriteria kualitatif yang sulit dikuantitatifkan secara eksak.

2) Masing-masing kriteria dapat memiliki subsubkriteria yang dapat dibentuk seperti hirarki

3) Penilaian dapat dilakukan oleh satu atau beberapapengambil keputusan secara sekaligus

4) Kandidat pilihan sudah tertentu dan terbatas jumlahnya

Apabila suatu permasalahan pengambilan keputusan ingin diselesaikan dengan metode AHP, permasalahan tersebut perlu dimodelkan sebagai hirarki umum, yakni tujuan, kriteria (termasuk sub-kriteria di bawahnya), dan alternatif. 
Sebagai contoh, misalnya seorang manajer dihadapkan permasalahan untuk memilih armada logistik yang paling sesuai.

Permasalahan ini dapat dimodelkan seperti model hirarki AHP di bawah.

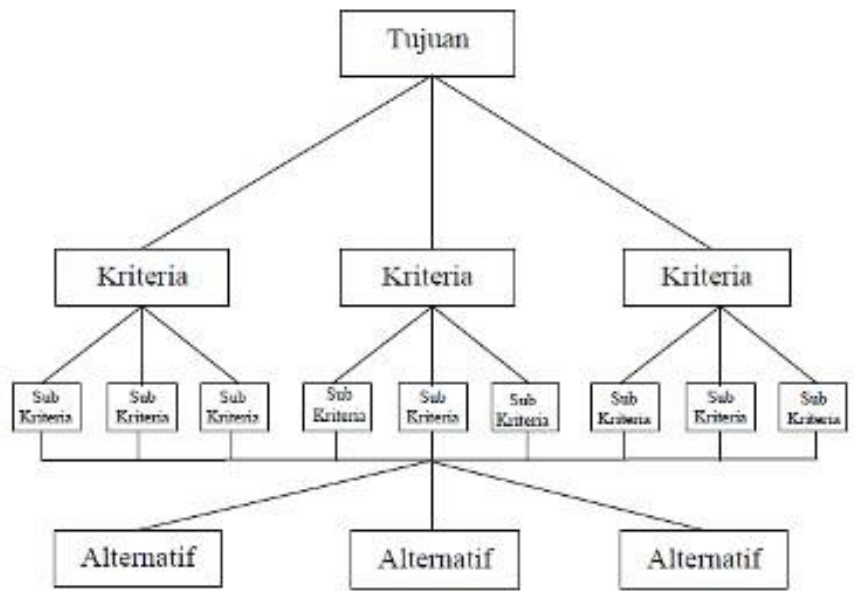

Gambar 1. Contoh Gambar Proses Pengambilan Keputusan dengan AHP

Dalam model di atas, terlihat ada beberapa level/baris yang membentuk sebuah hirarki. Level bagian atas adalah untuk merepresentasikan tujuan. Yaitu memecahkan masalah yang utuh menjadi unsur-unsurnya. Jika ingin mendapat hasil akurat, pemecahan juga dilakukan terhadap unsur-unsurnya sampai tidak mungkin dilakukan pemecahan lebih lanjut sehingga di dapat beberapa tingkatan dari persoalan tadi. Proses analisa ini dinamakan hirarki. Ada dua jenis hirarki, yaitu lengkap dan tidak lengkap. Dalam hirarki lengkap, semua elemen pada suatu tingkat memiliki semua elemen yang adapada tingkat berikutnya. Jika tidak demikian maka dinamakan hirarki tidak lengkap.

Konsep dasar dari AHP adalah penggunaan pairwise comparison matrix (matriks perbandingan berpasangan) untuk menghasilkan bobot relatif antar kriteria maupun alternatif. Suatu kriteria akan dibandingkan dengan kriteria lainnya dalam hal seberapa penting terhadap pencapaian tujuan di atasnya. Sebagai contoh, kriteria spesifikasi dan kriteria biaya akan dibandingkan seberapa pentingnya dalam hal memilih armada transportasi. Begitu juga untuk alternatif. Kendaraan A, B, dan C akan dibandingkan secara berpasangan (dan akan dibentuk matriks) dalam hal sub-kriteria biaya pemeliharaan.

Ada empat prinsip dasar AHP [7]:

1) Dekomposisi (Decompositon)

Yaitu memecahkan masalah yang utuh menjadi unsurunsurnya. Jika ingin mendapat hasil akurat, pemecahan juga dilakukan terhadap unsur-unsurnya sampai tidak mungkin dilakukan pemecahan lebih lanjut sehingga di dapat beberapa tingkatan dari persoalan tadi. Proses analisa ini dinamakan hirarki. Ada dua jenis hirarki, yaitu lengkap dan tidak lengkap. Dalam hirarki lengkap, semua elemen pada suatu tingkat memiliki semua elemen yang ada pada tingkat berikutnya. Jika tidak demikian maka dinamakan hirarki tidak lengkap.

2) Perbandingan Penilaian / Pertimbangan (Comparative Judgement)

Prinsip ini berarti membuat penilaian tentang kepentingan relatif dua elemen pada suatu tingkat tertentu dalam kaitannya dengan tingkat diatasnya. Penilaian ini merupakan inti dari AHP, karena ia akan berpengaruh terhadap prioritas elemen-elemen.

3) Sintesa Prioritas (Synthesis of Priority)

Dari setiap matriks pairwise comparison kemudian dicari eigen vector-nya untuk mendapatkan local priority. Karena matriks pairwise comparison terdapat semua tingkat, maka untuk mendapatkan global priority harus dilakukan sintesa diantara local priority. Prosedur melakukan sintesis berbeda menurut hierarki. Pengurutan elemen-elemen menurut kepentingan relative melalui prosedur sintesis dinamakan priority setting.

4) Konsistensi Logis (Logical Consistency). Konsistensi memiliki dua makna. Pertama adalah bahwa obyekobyek yang serupa dapat dikelompokkan sesuai dengan keseragaman dan relevansi. Arti kedua adalah menyangkut tingkat hubungan antara obyek-obyek yang didasarkan pada kriteria tertentu.

\section{Expert Choice 2000}

Mengapa dalam penelitian menggunakan metode AHP ini saya menggunakan Expert Choice 2000 sebagai tools?

Software atau perangkat lunak yang penulis gunakan dalam pengambilan keputusan berdasarkan metode Analytical Hierarchy Process (AHP) adalah Expert Choice 2000. Expert Choice 2000 adalah sebuah perangkat lunak yang mendukung collaborative decision dan sistem perangkat keras yang memfasilitasi grup mambuat keputusan yang lebih efisien, analitis, dan yang dapat dibenarkan. Memungkinkan interaksi real-time dari tim manajemen untuk mencapai consensus on decisions [2].

Beberapa kelebihan atau keunggulan Software Expert Choice 2000 diantaranya [4]:

1) Data Interchange Mapping, Importing and Exporting. Integrasi dengan eksternal Microsoft Access atau database SQL Server menyediakan konektivitas efisien, dan pelaporan capture data, dan mengurangi waktu entri data dan kesalahan

2) Multiple Models

Kemampuan untuk membuka beberapa model dengan mudah dan secara mudah memindah atau menghapus data dari satu model ke model lain, memudahkan proses pembuatan dan memungkinkan pengguna untuk berjalan side by side skenario untuk expedited analisis dan pengambilan keputusan.

3) Support for Microsoft SQL Models

Mengkonversi atau membuat model SQL dan menghubungkan ke database SQL perusahaan yang meningkatkan integrasi, lebih cepat dalam 
perhitungan model, model yang lebih besar, dan metode mencari dan menerima yang lebih baik.

4) User Friendly Interface

Memungkinkan pengguna untuk melihat informasi dokumen saat melakukan judgments dari data grid.

5) Enhanced Reporting

Fungsi baru eksternal untuk mengedit, menciptakan hubungan dengan data perusahaan, melihat data, dan menghilangkan ketidak konsistenan menyediakan fleksibilitas yang lebih besar dan hasil yang lebih baik secara keseluruhan.

6) Expert Choice Update

Mudah untuk meng-update software secara online menjamin pelanggan dapat mengakses perangkat lunak terbaru.

\section{Tinjauan Objek Penelitian}

Tinjaun objek penelitian berisi ulasan mendalam tentang beberapa metode yang digunakan dalam Internet Service Provider.

\section{1) GSM Global System for Mobile Communication (GSM)}

Global System for Mobile Communication (GSM) mulanya singkatan dari Groupe Special Mobile adalah sebuah teknologi komunikasi selular yang bersifat digital. Teknologi GSM banyak diterapkan pada komunikasi bergerak, khususnya telepon genggam. Teknologi ini memanfaatkan gelombang mikro dan pengiriman sinyal yang dibagi berdasarkan waktu, sehingga sinyal informasi yang dikirim akan sampai pada tujuan. GSM dijadikan standar global untuk komunikasi selular sekaligus sebagai teknologi selular yang paling banyak digunakan orang di seluruh dunia.

2) Code Division Multiple Access (CDMA) Di Era teknologi telekomunikasi, kecepatan, dan faktor ekonomis menjadi fokus utama dalam proses penyampaian informasi. Hal inilah yang prakarsai para ilmuwan untuk membuat suatu teknologi telekomunikasi yang cepat, murah, dan jangkauannya luas. Perkembangan ini mulai terlihat dengan adanya teknologi 1G. Selang beberapa waktu, teknologi $1 \mathrm{G}$ sudah dianggap mulai ketingggalan zaman, maka munculah teknologi $2 \mathrm{G}$ yang dibagi kedalam dua jenis, teknologi GSM dan teknologi Code Division Multiple Access (CDMA). Code Division Multiple Access atau sering disingkat dengan CDMA adalah sebuah pemultipleksan (bukan sebuah skema pemodulasian) dan sebuah metode akses secara bersama yang membagi kanal tidak berdasarkan waktu (seperti pada TDMA) atau frekuensi (seperti pada FDMA), namun dengan cara mengkodekan data dengan sebuah kode khusus yang diasosiasikan dengan tiap kanal yang ada dan menggunakan sifat - sifat interfensi kontruktif dari kode - kode khusus itu untuk melakukan pemultipleksan. CDMA mengacu pada sistem telepon seluler digital yang menggunakan skema akses secara bersama ini seperti yang diprakarsai QUALCOMM. Teknologi wireless ini pada dasarnya lahir Karen adanya teori tentang gelombang elektromagnetik yang dikemukakan oleh Maxwell di tahun 1850-an. Adanya gelombang elektromagnetik ini kemudian dibuktikan oleh H.Hertz pada tahun 1888. Kemudian pada tahun 1895 Guilermo Marconi mentransmisikan gelombang radio untuk pertama kalinya. Pada tahun 1901 Marconi menggunakan gelombang radio untuk transmisi jarak jauh (transatlantik) dengan kode morsenya. Seiring berkembangnya teknik elektronika sejak tahun 1906 gelombang elektromagnetik mulai dipakai untuk system siaran (broadcasting). Dalam system broadcasting ini gelombang elektromagnetik merupakan syarat pembawa informasi dan hiburan. Selanjutnya terjadi perkembangan penyiaran secara cepat di tahun 1920-an, ketika di rumah-rumah telah ada pesawat penerima wireless. CDMA (Code Division Multiple Access), menggunakan teknologi spread-spectrum untuk mengedarkan sinyal informasi yang melalui bandwith yang lebar (1,25 MHz). CDMA juga merupakan sebuah bentuk pemultipleksan (bukan sebuah skema pemodulasian) dan sebuah metode akses secara bersama yang membagi kanal tidak berdasarkan waktu (seperti pada TDMA) atau frekuensi (seperti pada FDMA), namun dengan cara mengkodekan data dengan sebuah kode khusus yang diasosiasikan dengan tiap kanal yang ada dan mengunakan sifat-sifat interferensi konstruktif dari kode-kode khusus itu untuk melakukan pemultipleksan.Teknologi ini asalnya dibuat untuk kepentingan militer, menggunakan kode digital yang unik, lebih baik daripada channel atau frekuensi RF.

Saat ini teknologi CDMA sedang hangat dibicarakan, khususnya dengan masuknya PT. TELKOM dengan produk TelkomFlexi-nya. Dari aspek teknologi baik GSM maupun CDMA merupakan standar teknologi seluler digital, hanya bedanya GSM dikembangkan oleh negara-negara eropa dan bersifat $\mu$ open source,', sedangkan CDMA dari kubu Amerika dan Jepang. Yang perlu diperhatikan bahwa teknologi GSM dan CDMA berasal dari jalur yang berbeda, sehingga perkembangan ke generasi 2,5G dan 3G berikutnya akan berbeda terus. Teknologi CDMA didesain tidak peka terhadap interfensi, dan sejumlah pelanggan dalam satu sel dapat mengakses pita spektrum frekuensi secara bersama karena mempergunakan teknik pengkodean tertentu. Ponsel CDMA ada dua jenis, tanpa kartu sehingga nomer panggilnya harus di program oleh petugas operator yang bersangkutan, dan satu lagi ponsel CDMA yang dilengkapi dengan RUIM (Removal User Identification Module) atau dalam 
istilah GSM dikenal dengan SIM Card.

Berikut adalah evolusi dari jaringan cellular CDMA

"Code Division Multiple Access":

a. Teknologi CDMA $1 \mathrm{X}$ memiliki kecepatandownload maksimal $153 \mathrm{Kbps}$

b. Teknologi EVDO Rev O kecepatan download maksimal 2.4 Mbps

c. Teknologi EVDO Rev A memiliki kecepatan download maksimal 3.1 Mbps

d. Teknologi EVDO Rev B memiliki kecepatan download maksimal 14.7 Mbps

EVDO yaitu singkatan dari Evolution Data Optimized yaitu teknologi dari jaringan CDMA. Saat ini di Indonesia, EVDO terbagi 2 yaitu Rev O dan Rev A dan yang masih dalam tahap pengembangan akan muncul EVDO Rev B. Teknologi CDMA EVDO ini diyakini memiliki kecepatan dan tarif yang bersaing dengan GSM 3G HSDPA. Untuk teknologi EVDO sementara ini baru dapat dinikmati dengan layanan dari Fren dengan produk Mobile nya dan operator SMART. Sedikit penjelasan tentang tingkatan kecepatan koneksijaringan CDMA karena perkembangannya tidak seperti operator GSM yang sangat cepat.

3) Pengenalan Paket Layanan Internat Operator GSM Paket internet adalah sebuah layanan yang disediakan oleh operator telekomunikasi atau data dimana konsumen diharuskan untuk membayar sejumlah nominal rupiah sebagai biaya pemakaian internet (data). Bagi pengguna telepon seluler, bila tidak menggunakan paket internet, maka setiap kali melakukan koneksi data (internet), biayanya diambil dari pulsa telepon. Berikut ini beberapa paket layanan internet operator GSM yang kami ambil dari empat operator GSM terbesar di Indonesia, yaitu :

a) XL Internet Hotrod $3 \mathrm{G}+$

XL Internet Hotrod 3G+ adalah layanan paket internet yang di keluarkan oleh PT XL Axiata, Tbk untuk menggantikan paket layanan internet sebelumnya yaitu XL Unlimited.

b) Telkomsel Flash

Telkomsel Flash adalah layanan internet tanpa kabel (wireless) yang disediakan oleh TELKOMSEL untuk seluruh pelanggannya (kartuHALO, simPATI dan Kartu As). Layanan ini didukung dengan teknologi HSDPA/3G / EDGE /GPRS yang dapat menghasilkan kecepatan download sampai dengan 14.4 mbps.

c) Indosat Super $3 \mathrm{G}+$

Indosat Super 3G+ adalah layanan internet data yang dikeluarkan oleh PT. Indosat Tbk, untuk memberikan keleluasaan pelanggan berselancar di dunia maya di jaringan $2 \mathrm{G}$ ataupun $3 \mathrm{G}$ dengan kecepatan hingga 7.2 mbps dan kuota terbesar sampai dengan 7.5 GB.

d) Three Kuota ++

PT. Hutchison CP Telecommunications (HCPT) adalah perusahaan penyedia jasa telekomunikasi yang berkembang pesat dan beroperasi dengan lisensi nasional 2G/GSM $1800 \mathrm{Mhz}$ dan 3G/WCDMA di Indonesia. HCPT menyediakan beragam layanan telekomunikasi bergerak berkualitas dan inovatif di bawah merek "3". HCPT menawarkan inovasi tarif dan produk dengan pengembangan cakupan layanan yang sangat pesat guna menjadi operator dengan cakupan layanan nasional terkemuka di Indonesia.Paket Kuota ++ dikatakan sebagai jodohnya paket Always On karena jika kedua paket ini digabungkan baru bisa menikmati kebebasan berinternet.

4) Pengenalan Paket Layanan InternetOperator CDMA

PT Smartfren Telecom, Tbk. adalah operator penyedia jasa telekomunikasi berbasis teknologi CDMA yang memiliki lisensi selular dan mobilitas terbatas (fixed wireless access), serta memiliki cakupan jaringan CDMA EV-DO (jaringan mobile broadband yang setara dengan 3G) yang terluas di Indonesia. Smartfren juga merupakan operator telekomunikasi pertama di dunia yang menyediakan layanan CDMA EV-DO Rev. B (setara dengan 3,5G dengan kecepatan unduh s.d. 14,7 Mbps) dan operator CDMA pertama yang menyediakan layanan Blackberry. Jasa dan layanan Smartfren memiliki nilai-nilai (values) yaitu sebagai mitra yang terbaik bagi pelanggan dengan menawarkan solusi yang cerdas dalam layananlayanan telekomunikasi untuk meningkatkan pengalaman hidup pelanggan dalam berkomunikasi.

Sebagai operator CDMA yang menyediakan jaringan internet kecepatan tinggi bergerak (mobile broadband) yang terluas di Indonesia, Smartfren berkomitmen untuk menjadi penyedia layanan telekomunikasi yang terjangkau bagi masyarakat dengan kualitas terbaik.

5) Jenis - Jenis Kartu Layanan Internet.

Kartu layanan internet ada dua macam, yaitu :

a) Kartu Prabayar

Kartu prabayar adalah suatu kartu telepon yang pembayarannya dilakukan pada awal pembayaran sebelum digunakan.

b) Kartu Pasca Bayar

Kartu pasca bayar adalah kartu telepon yang pembayarannya dilakukan diakhir atau setelah penggunaan.

6) Kuota Paket Internet GSM

Kuota paket internet adalah batas pemakaian 
internet yang ditentukan oleh provider telepon. Kuota bisa ditentukan berdasarkan :

a) Volume Based

Volume based adalah cara penghitungan tarif koneksi berdasarkan jumlah volume pemakaian data selama koneksi internet berlangsung, tergantung banyaknya data yang diunduh (download) ditambah dengan data yang di unggah (upload). Biasanya ditentukan dengan ukuran MB (megabyte) atau GB (gigabyte). 1 $\mathrm{GB}=1000 \mathrm{MB}$.

b) Time Based

Time based adalah cara penghitungan tarif koneksi berdasarkan lamanya waktu pemakaian selama koneksi internet berlangsung. Hitungannya biasanya dikenakan per menit penggunaan.

c) Unlimted

Unlimited adalah akses pemakaian internet tanpa batas.

\section{7) Tingkatan Jaringan Operator}

Berikut ini adalah beberapa tingkatan jaringan operator layanan telekomunikasi yang ada di Indonesia :

a) GPRS (General Packet Radio Services)

Yaitu perkembangan dari teknologi GSM dengan kecepatan komunikasi data sampai $115 \mathrm{kbps}$ karena sistem GPRS dapat digunakan untuk transfer data (dalam bentuk paket data) yang berkaitan dengan e-mail, data gambar (MMS), Wireless Application Protocol (WAP), dan World Wide Web (WWW).

b) EDGE (Enhanced Data rates for GSM

Evolution)Sebelumnya pada GPRS menawarkan kecepatan data sebesar $115 \mathrm{kbps}$, dan secara teori dapat mencapai 160 kbps. Sedangkan pada EDG kecepatan datanya sbesar $384 \mathrm{kbps}$, dan secara teori dapat mencapai 473,6 kbps. Secara umum kecepatan EDGE tiga kali lebih besar dari GPRS.

c) UMTS/WCDMA/3G

UMTS (Universal Mobile Telecommunication System) dan biasa disebut juga dengan WCDMA (Wideband Code-division Multiple Access) merupakan teknologi generasi ketiga (3G) untuk GSM. Kecepatan WCDMA bisa mencapai $384 \mathrm{kbps}$ dan dimasa akan datang akan meningkat sampai mungkin sekitar 10 mbps. Teknologi ini menggunakan WidebandAMR (Adaptive Multi-rate) untuk kodifikasi suara (voice codec) sehingga kualitas suara yang didapat menjadi lebih baik dari generasi sebelumnya.

d) HSDPA (High Speed Downlink Packet Access) / HSUPA (High Speed Upload Packet Access)
Sebenarnya kedua teknologi ini berbeda tetapi kedua teknologi ini selalu satu paket, artinya di mana ada HSDPA di situ ada HSUPA. HSDPA merupakan standar HSPA dengan kemampuan dari sisi kecepatan transfer downlink-nya (dari jaringan ke handset), dimana HSDPA dapat mencapai kecepatan downlink 7.2 mbps dan secara teori dapat ditinggkatkan sampai kecepatan 14.4 mbps dengan maksimum uplink 384 kbps. HSDPA selain dapat digunakan oleh handphone tetapi dapat pula digunakan oleh notebook untuk mengakses data dengan kecepatan tinggi. Sedangkan HSUPA merupakan standar HSPA dengan kemampuan dari sisi kecepatan transfer uplink-nya (dari handset ke jaringan), dimana HSUPA dapat mencapai kecepatan uplink secara teori sampai kecepatan 5.76 mbps, tetapi HSUPA ini tidak implentasikan (dikomersialkan) dan handset-nya tidak dibuat tetapi tidak menutup kemungkinan handset-nya bisa dibuatkan oleh vendor tertentu.

e) HSPA (High Speed Packet Access)

Adalah penyatuan dari HSDPA dan HSUPA, untuk urusan kecepatan, HSDPA memliki kecepatan yang lebih ketimban EDGE dan GPRS. Hanya saja tidak semua wilayah di Indonesia terjangkau oleh HSDPA.

\section{DESAIN PENELITIAN}

Metodologi penelitian adalah salah satu unsur penting dalam suatu penelitian ilmiah, karena ketepatan metode yang digunakan untuk memecahkan masalah yang ada akan menentukan hasil penelitian itu dapat dipertanggungjawabkan atau tidak. Adapun metodologi yang digunakan dalam penelitian ini sebagai berikut :

\section{A. Jenis Penelitian}

Penelitian ini merupakan penelitian kuantitatif yaitu penelitian tentang masalah kemasyarakatan atau kemanusiaan yang didasarkan pada pengujian suatu teori yang tersusun atas variabel-variabel, diukur dengan bilangan-bilangan, dan dianalisis dengan prosedur-prosedur statistik. Jenis data dalam penelitian ini masuk ke dalam kategori data sekunder yaitu data primer yang telah diolah oleh pihak lain dan disajikan dalam bentuk tabel ataupun diagram dan merupakan data kuantitatif yaitu data yang berupa data atau bilangan dimana mereduksi data menjadi angka. Penelitian kuantitatif merupakan suatu penelitian yang analisisnya secara umum memakai analisis statistik. Karenanya dalam penelitian kuantitatif pengukuran terhadap gejala yang diamati menjadi penting, sehingga pengumpulan data dilakukan dengan menggunakan daftar pertanyaan berstruktur yang disusun berdasarkan pengukuran terhadap variable yang diteliti yang kemudian menghasilkan data kuantitatif. Penelitian kualitatif yang menekankan pada studi kasus, penelitian kuantitatif berkaitan dengan survey. 


\section{B. Pemilihan Sampel}

Sampel (contoh) ialah sebagian anggota populasi yang diambil dengan menggunakan teknik tertentu yang disebut dengan teknik sampling. Teknik sampling berguna agar mereduksi anggota populasi menjadi anggota sampel yang mewakili populasinya sehingga kesimpulan terhadap populasi dapat dipertanggungjawabkan, lebih teliti menghitung yang sedikit dari pada yang banyak, menghemat waktu tenaga dan biaya. Sampel adalah sebagian dari populasi yang memiliki sifat dan karakter yang sama, sehingga betul-betul mewakili populasinya.

Populasi ialah semua nilai baik hasil perhitungan maupun pengukuran, baik kuantitatif maupun kualitatif, dari pada karakteristik tertentu mengenai sekelompok obyek yang lengkap dan jelas. Populasi adalah keseluruhan subyek penelitian. Populasi dalam setiap penelitian harus disebutkan secara tersurat yaitu yang berkenaan dengan besarnya anggota populasi serta wilayah penelitian yang dicakup. Ditinjau dari banyaknya anggota populasi, populasi terdiri atas :

a) Populasi terbatas (terhingga)

b) Populasi tidak terbatas (tidak terhingga) ditinjau dari sudut sifatnya, populasi terdiri atas : Homogen dan Heterogen

Dalam pemilihan sampel, penulis mengambil data dari populasi yang terbatas dengan menggunakan purposive sampling, yaitu pengambilan sampel dilakukan atas dasar pertimbangan tertentu. Responden yang diambil dalam pemilihan sampel ini adalah responden ahli yaitu agency pospay di Pangkalpinang. Pertimbangan pemilihan sampel yang berdasarkan kategorisasi atau latar belakang responden di atas, antara lain agar penilaian terhadap internet service provider ini lebih variatif dan objektif.

Tabel 1. Tabel Responden

\begin{tabular}{|l|l|l|}
\hline \multicolumn{1}{|c|}{ No. } & \multicolumn{1}{|c|}{ Responden } & Jumlah \\
\hline 1. & Agency Rayya & 1 \\
\hline 2. & Agency Pos Permata & 1 \\
\hline 3. & Agency Patra Shidqindo & 1 \\
\hline 4. & Agency Rio & 1 \\
\hline 5. & Agency Alfatih & 1 \\
\hline 6. & Agency Shiauchin & 1 \\
\hline \multicolumn{2}{|r|}{ Jumlah } & $\mathbf{6}$ \\
\hline
\end{tabular}

\section{Instrumentasi}

Berdasarkan metode pengumpulan data dalam penelitian ini, maka instrumentasi yang dipakai terdiri dari:

1) Menentukan kriteria, subkriteria dan alternative yang merupakan bahan untuk penyusunan kuesioner. Menyusun Kuesioner yang bersifat tertutup sesuai dengan kriteria, subkriteria dan alternatif.

2) Pengambilan sampel ditentukan secara purposive sampling.

3) Melakukan pengumpulan data dengan membagikan kuesioner kepada expert judgement.

4) Melakukan Pengolahan data dengan Expert Choice.

5) Melakukan analisis data dan pembuatan laporan penelitian.

Dalam menentukan prioritas langkah pilihan strategis pada penentuan internet service provider ini diusulkan 20 (dua puluh) sub kriteria yang dikelompokan ke dalam 6 (enam) kriteria utama. Penyusunan dan pengelompokan kriteria utama ini berdasarkan hirarki yang disesuaikan dengan beberapa poin keunggulan internet service provider yang menjadi objek penelitian yaitu XL; Telkomsel, Indosat, Three (3), dan Smartfren.

Rincian sub kriteria dalam strategi pemilihan internet service provider, disusun sebagai berikut :

1) Kemudahan pengguna, terdiri dari beberapa sub kriteria yaitu : Aktivasi layanan, Bonus paket, Informasi layanan, Jangkauan jaringan.

2) Kecepatan transfer data, terdiri dari beberapa sub kriteria yaitu : 115 - $160 \mathrm{Kbps}, 384$ - 473,6 Kbps, 384 - 10 Mbps, 7,2 - 14,4 Mbps.

3) Jenis layanan, terdiri dari beberapa sub kriteria, yaitu : Prabayar, Pascabayar.

4) Batasan akses internet / kuota, terdiri dari beberapa sub kriteria yaitu : Time based, Volume based, Unlimited.

5) Tingkatan jaringan, terdiri dari beberapa sub kriteria yaitu : GPRS, EDGE, UMTS, HSDPA, HSPA.

6) Jenis kartu, terdiri dari beberapa sub kriteria yaitu : GSM, CDMA.

Berdasarkan kriteria dan sub kriteria yang ada pada uraian tersebut, maka berikut adalah hirarki AHP yang terbentuk dari urutan kriteria dan sub kriteria.

Berikut hirarki AHP dalam pemilihan service provider terbaik di Pangkalpinang :

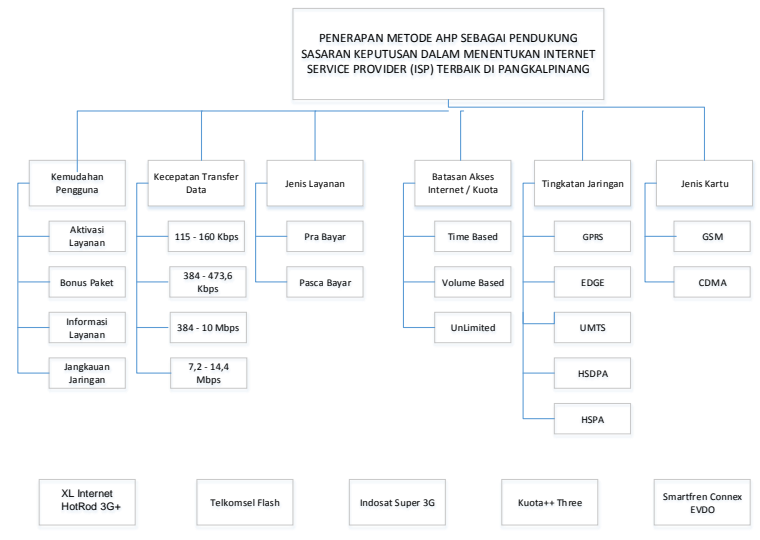

Gambar 1. Hirarki Pemilihan Internet service provider terbaik di Pangkalpinang 
Dari gambar 1 di atas dilihat bahwa terdapat enam elemen kriteria di level 1 dan dua puluh elemen kriteria di level 2 yang menjadi pertimbangan dalam pemilihan internet service provider terbaik di Pangkalpinang yang masing - masing elemen kriteria mempunyai lima elemen alternatif.

Dari data-data yang didapatkan melalui kuisioner, nilai-nilai numeric antar elemen dari setiap perbandingan berpasangan diproses dalam sebuah matriks perbandingan. Berdasarkan banyaknya ukuran sample, maka untuk mendapatkan nilai setiap bobot antar elemen digunakan metode rata-rata ukur dengan perhitungan nilai gabungan.

Dari gambar III.1 di atas dilihat bahwa terdapat tujuh elemen kriteria di level 1 dan 20 elemen kriteria di level 2 yang menjadi pertimbangan dalampemilihan internet service provider terbaik di Pangkalpinang yang masing - masing elemen kriteria mempunyai lima elemen alternatif.

Dari data-data yang didapatkan melalui kuisioner, nilai-nilai numeric antar elemen dari setiap perbandingan berpasangan diproses dalam sebuah matriks perbandingan. Berdasarkan banyaknya ukuran sample, maka untuk mendapatkan nilai setiap bobot antar elemen digunakan metode rata-rata ukur dengan perhitungan nilai gabungan.

\section{Jadwal Penelitian}

Penelitian ini dibuat berdasarkan jadwal mulai dari persiapan sampai menyajikannya dalam laporan penelitian.

A. Persiapan

1) Melakukan studi literatur, yaitu dengan mencari referensi dari berbagai media, buku, jurnal, majalah ilmiah maupun website yang dapat dijadikan landasan teori penelitian,

2) Membuat rancangan penelitian dan metode penelitian yang sesuai,

3) Membuat alat penelitian, termasuk membuat instrumen berupa kuesioner.

B. Pengumpulan Data

Mengambil data pada petugas loket agency pospay Pangkalpinang sebagai tempat para responden ahli yang menjadi rujukan agar sesuai metode pengumpulan data.

C. Pengolahan Data

1) Entry Data Responden

2) Hitung data responden dengan Expert Choice 2000

3) Analisis Data hasil perhitungan Expert Choice 2000

4) Menyusun Laporan Penelitian

\section{HASIL PENELITIAN}

Internet service provider yang digunakan sebagai alternatif dalam penelitian adalah dengan kategori jumlah pemakai terbanyak di Pangkalpinang, utamanya yang banyak dimanfaatkan oleh kalangan agency Pospay PT.Pos Indonesia maupun di kalangan pendidikan dasar dan menengah bahkan masyarakat pada umunya. Dari hasil penelitian sebelumnya diketahui ada tiga paket Internet Provider yang paling banyak digunakan, yaitu Internet HotRot 3G+ (XL), Telkomsel Flash (Telkomsel), dan Indosat Super 3G+ (Indosat) .

Langkah selanjutnya yang dilakukan dalam Analytical Hierarchy Process adalah melakukan perbandingan berpasangan (pairwise comparison) terhadap kriteria (level 2) yang telah ditetapkan sebelumnya. Data-data yang diambil dari proses kuesioner terhadap 4 responden yang dipilih dengan teknik sampling jenuh akan dimasukkan ke dalam software Expert Choice 2000 untuk dilakukan proses perbandingan tersebut seperti yang terlihat pada gambar 2 berikut

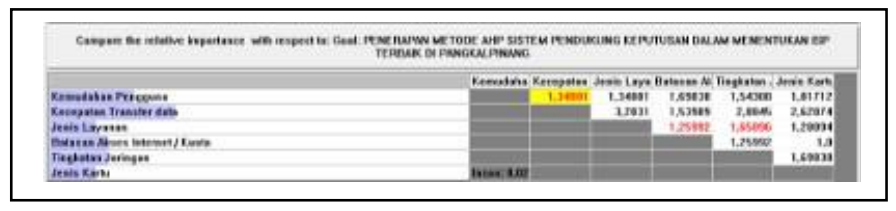

Gambar 2 Perbandingan berpasangan level 2 pada Expert

Choice 2000 [1]

Nilai-nilai yang tertera pada gambar tersebut merupakan nilai yang diambil setelah melalui proses mencari rata-rata dari data kuesioner terhadap 6 responden. Responden dalam penelitian pemilihan internet service provider terbaik di Pangkalpinang ini seluruhnya merupakan responden ahli yang berjumlah 6 (enam) orang. Pengertian responden ahli dalam hal ini adalah seluruh responden sangat memahami tentang obyek yang diteliti, serta pernah mengimplementasikan perangkat lunak tersebut dalam pekerjaannya.Proses selanjutnya yang dilakukan adalah membuat perbandingan berpasangan untuk level 3 yakni alternatif. Setiap alternative yang ada akan dilakukan perbandingan untuk masing-masing kriteria. Data untuk proses ini diambil melalui kuesioner yang diberikan kepada 6 responden, setelah itu data tersebut diolah dengan menggunakan Expert Choice 2000 untuk mendapatkan nilai rata-rata dari setiap perbandingan. Adapun tanggapan responden ahli terhadap kuesioner dapat dilihat pada hasil penggabungan responden akan ditunjukkan dengan Perbandingan berpasangan alternatif untuk level 2, hasilnya seperti pada gambar 3 berikut :

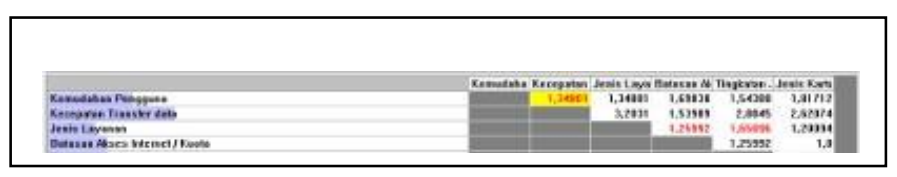

Gambar 3 Hasil Penggabungan Responden Terhadap Kriteria

Analisis pendapat gabungan para responden menunjukkan bahwa kriteria "Kecepatan transfer data" (nilai bobot 0,299 atau sebanding dengan $29,9 \%$ dari total kriteria) merupakan kriteria yang paling penting dalam pemilihan internet service provider terbaik di Pangkalpinang ini.

Berikut ini disajikan bobot masing - masing kriteria Kecepatan transfer data terbaik di Pangkalpinang. 


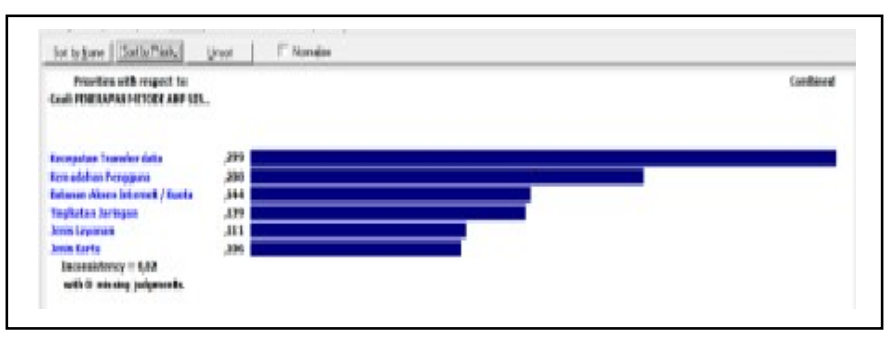

Gambar 4 Kriteria Penentuan internet service provider terbaik di Pangkalpinang Berserta Nilai Bobotnya

Kriteria berikutnya yang mempengaruhi dalam penentuan internet service provider terbaik di Pangkalpinang adalah "Tingkatan jaringan" (nilai bobot 0,139 atau sebanding dengan $13,9 \%$ dari total kriteria). Kriteria berikutnya yang mempengaruhi dalam penentuan internet service provider terbaik di Pangkalpinang adalah "Jenis layanan" (nilai bobot 0,111 atau sebanding dengan $11,1 \%$ dari total kriteria). Kriteria berikutnya yang mempengaruhi dalam penentuan internet service provider terbaik di Pangkalpinang adalah "Jenis kartu" (nilai bobot 0,106 atau sebanding dengan 10,6\% dari total kriteria). Kriteria Kecepatan transfer data yang mendapatkan point tertinggi dari responden ahli, memiliki 4 (Empat) sub kriteria, yaitu 1) 7,2-14,4 Mbps; 2) 384-10Mbps; 3) 384-473,6 Kbps; 4) 115-160 Kbps. Berikut hasil penggabungan responden ahli beserta bobotnya:

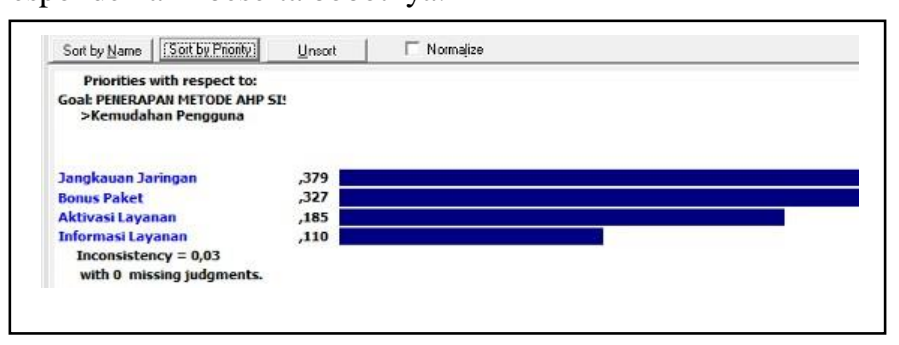

Gambar 5. Pemilihan internet service provider terbaik di Pangkalpinang Berserta Nilai Bobotnya

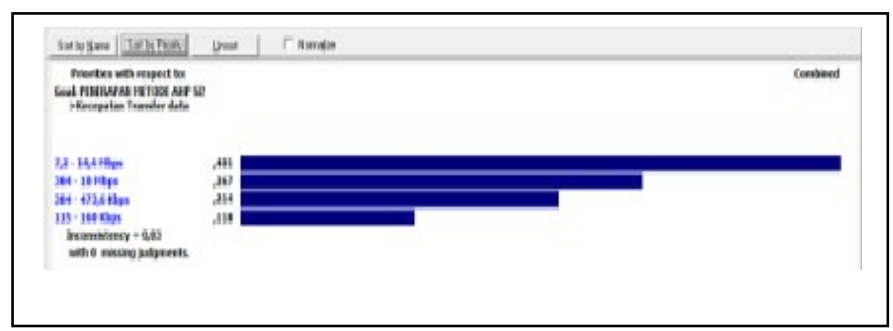

Gambar 6 Sub Kriteria dari kriteria kemudahan pengguna dalam

Hasil responden ahli memperlihatkan masalah kecepatan transfer data 7,2-14,4 Mbps mendapatkan sorotan tajam (Nilai bobot 0,401 atau setara dengan 40,1\% dari total sub kriteria yang ada). Faktor kecepatan transfer data 7,2-14,4 Mbps sangat penting dalam memilih internet service provider terbaik di Pangkalpinang, karena akan berpengaruh besar dalam penggunaan layanan jaringan yang disediakan oleh provider.

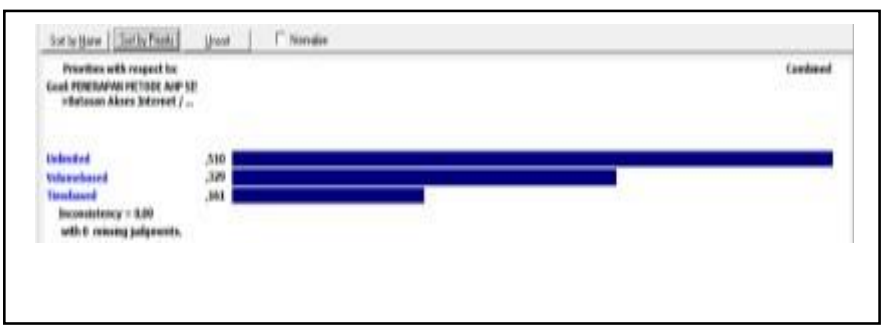

Gambar 7 Sub Kriteria dari kriteria batasan akese internet/kuota dalam Pemilihan internet service provider terbaik di Pangkalpinang Berserta Nilai Bobotnya

Adapun kriteria Batasan akses internet / kuota yang menempati urutan ketiga memiliki 3 (tiga) sub kriteria, yaitu: 1) Timebased; 2) Volumebased; dan 3) Unlimited. Dari ketiga sub kriteria ini, sub kriteria paling utama yang dinilai oleh responden ahli adalah sub kriteria Unlimited (nilai bobot 0,510 atau $51,0 \%$ dari total sub kriteria yang ada). Hasil ini sangat relevan dengan kenyataan bahwa unsur Unlimited tersebut penghitungan tarif koneksi yang tanpa batas selama koneksi internet berlangsung atau tanpa ada perhitungan Time atau Volume based lagi.

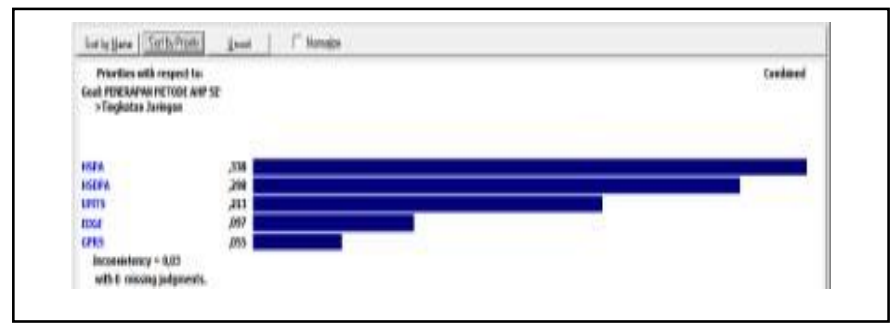

Gambar 8 Sub Kriteria dari kriteria tingkatan jaringan dalam Pemilihan internet service provider terbaik di Pangkalpinang Berserta Nilai Bobotnya

Adapun kriteria Tingkatan jaringan yang menempati urutan keempat memiliki 5 (lima) sub kriteria, yaitu: 1) GPRS; 2) EDGE; 3) UMTS; 4) HSDPA dan 5) HSPA. Dari kelima sub kriteria ini, sub kriteria paling utama yang dinilai oleh responden ahli adalah sub kriteria HSPA (nilai bobot 0,338 atau $33,8 \%$ dari total sub kriteria yang ada). Hasil ini sangat relevan dengan kenyataan bahwa unsur HSPA tersebut memiliki kecepatan akses yang paling tinggi.

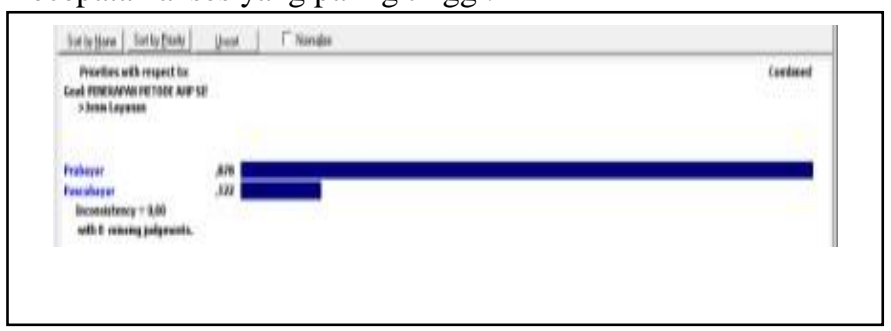

Gambar 9 Sub Kriteria dari jenis layanan dalam Pemilihan internet service provider terbaik di Pangkalpinang Berserta Nilai Bobotnya

Adapun kriteria Jenis Kartu yang menempati urutan keenam memiliki 2 (dua) sub kriteria, yaitu: 1) GSM; 2) CDMA. Dari kedua sub kriteria ini, sub kriteria paling utama yang dinilai oleh responden ahli adalah sub kriteria GSM (nilai bobot 0,878 
atau $87,8 \%$ dari total sub kriteria yang ada).

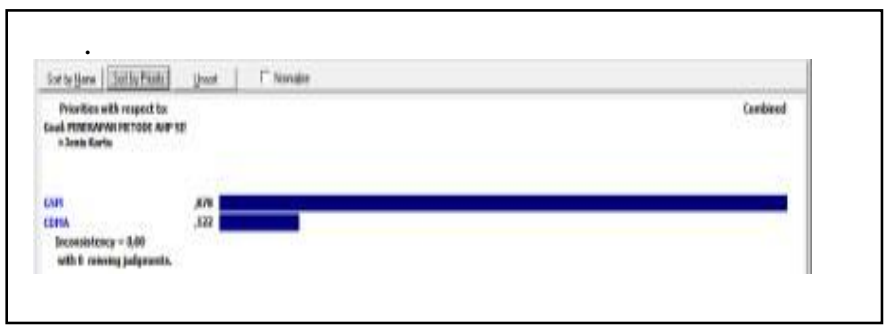

Gambar 10 Sub Kriteria dari Jenis Kartu dalam Pemilihan internet service provider terbaik di Pangkalpinang Berserta Nilai Bobotnya

Adapun kriteria Jenis layanan yang menempati urutan kelima memiliki 2 (dua) sub kriteria, yaitu: 1) Prabayar; 2) Pascabayar; Dari kedua sub kriteria ini, sub kriteria paling utama yang dinilai oleh responden ahli adalah sub kriteria Prabayar (nilai bobot 0,878 atau $87,8 \%$ dari total sub kriteria yang ada). Hasil ini sangat relevan dengan kenyataan bahwa unsur prabayar tersebut kartu prabayar GSM adalah suatu kartu telepon GSM yang pembayarannya dilakukan pada awal pembayaran sebelum digunakan

Setelah melalui proses pengisian kuesioner oleh beberapa responden ahli, dan melalui perhitungan geometris penggabungan data responden diperoleh nilai bobot alternatif seperti yang disajikan pada grafik berikut

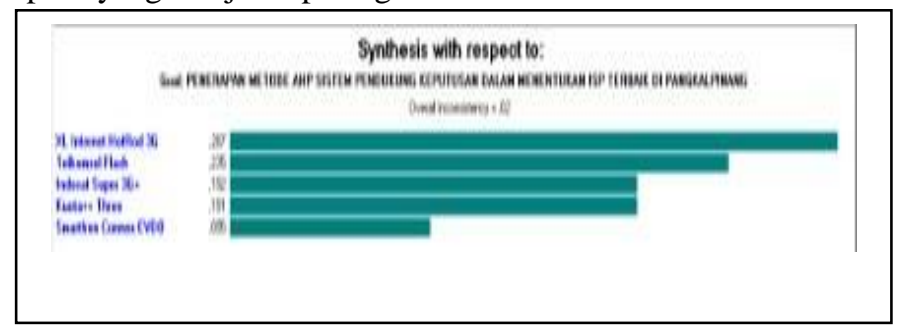

Gambar IV-57 Nilai Bobot Global Prioritas Alternatif berdasarkan Sasaran Memilih Internet Service Provider terbaik di Pangkalpinang

Berdasarkan hasil pengolahan data responden ahli diperoleh bahwa prioritas utama atau tertinggi alternatif penentuan Internet Service Provider terbaik di Pangkalpinang adalah XL Internet HotRod 3G dengan nilai bobot 0,287 atau sebanding dengan $28,7 \%$ dari total alternatif yang ditetapkan. Kemudian peringkat prioritas alternatif berikutnya adalah Telkomsel Flash (nilai bobot 23,5\%), selanjutnya Indosat Super 3G+ (nilai bobot 19,2\%), Kuota++ Three (nilai bobot 19,1) dan peringkat prioritas terendah adalah Smartfren Connex EVDO (nilai bobot 09,5\%).

Inconsistency ratio atau rasio inkonsistensi data responden merupakan parameter yang digunakan untuk memeriksa apakah perbandingan berpasangan telah dilakukan dengan konsekuen atau tidak. Rasio inkonsistensi data dianggap baik jika nilai CR-nya $\leq 0.1$. Untuk mengecek rasio inkonsistensi data responden, berikut ini ditampilkan nilai rasio inkonsistensi pada masing - masing matriks perbandingan
Tabel 2. Perbandingan elemen dan nilai CR

\begin{tabular}{|c|c|c|}
\hline No & Matriks Perbandingan Elemen & $\begin{array}{c}\text { Nilai } \\
\text { CR }\end{array}$ \\
\hline 1. & $\begin{array}{l}\text { Perbandingan elemen criteria Level I berdasarkan } \\
\text { sasaran pemilihan Internet service provider terbaik di } \\
\text { Pangkalpinang }\end{array}$ & 0,02 \\
\hline 2. & $\begin{array}{l}\text { Perbandingan elemen sub criteria level II berdasarkan } \\
\text { sasaran-kriteria: pemilihan Internet service provider } \\
\text { terbaik di Pangkalpinang kriteria Kemudahan Pengguna }\end{array}$ & 0,03 \\
\hline 3. & $\begin{array}{l}\text { Perbandingan elemen sub criteria level II berdasarkan } \\
\text { sasaran kriteria: pemilihan Internet service provider } \\
\text { terbaik di Pangkalpinang kriteria Kecepatan transfer } \\
\text { data }\end{array}$ & 0,03 \\
\hline 4. & $\begin{array}{l}\text { Perbandingan elemen sub criteria level II berdasarkan } \\
\text { sasaran-kriteria: pemilihan Internet service provider } \\
\text { terbaik di Pangkalpinang kriteria Jenis Layanan }\end{array}$ & 0,00 \\
\hline 5. & $\begin{array}{l}\text { Perbandingan elemen sub Kriteria level II berdasarkan } \\
\text { sasaran-kriteria: pemilihan Internet Service Provider } \\
\text { terbaik di Pangkalpinang kriteria Batasan Akses } \\
\text { Internet/kuota }\end{array}$ & 0,00 \\
\hline 6. & $\begin{array}{l}\text { Perbandingan elemen sub criteria level II berdasarkan } \\
\text { sasaran-kriteria: pemilihan Internet service provider } \\
\text { terbaik di Pangkalpinang Kriteria Tingkatan Jaringan }\end{array}$ & 0,03 \\
\hline 7. & $\begin{array}{l}\text { Perbandingan elemen sub kriteria level II } \\
\text { berdasarkan sasaran-kriteria Pemilihan } \text { Internet } \\
\text { service provider terbaik di Pangkalpinang kriteria } \\
\text { Jenis Kartu }\end{array}$ & 0,00 \\
\hline 8. & $\begin{array}{l}\text { Perbandingan elemen alternative level III berdasarkan } \\
\text { sasaran-kriteria-sub kriteria: pemilihan Internet service } \\
\text { provider terbaik di Pangkalpinang kriteria Kemudahan } \\
\text { Pengguna sub kriteria Aktivasi Layanan }\end{array}$ & 0,01 \\
\hline 9. & $\begin{array}{l}\text { Perbandingan elemen alternative level III } \\
\text { berdasarkan sasaran-kriteria-sub kriteria: pemilihan } \\
\text { Internet service provider terbaik di Pangkalpinang } \\
\text { kriteria Kemudahan Pengguna sub kriteria Bonus } \\
\text { Paket }\end{array}$ & 0,01 \\
\hline 10.' & $\begin{array}{l}\text { Perbandingan elemen alternative level III berdasarkan } \\
\text { sasaran-kriteria-sub kriteria: pemilihan Internet service } \\
\text { provider terbaik di Pangkalpinang kriteria Kemudahan } \\
\text { Pengguna sub kriteria Informasi Layanan }\end{array}$ & 0,01 \\
\hline 11. & $\begin{array}{l}\text { Perbandingan elemen alternative level III berdasarkan } \\
\text { sasaran-kriteria sub kriteria: pemilihan Internet service } \\
\text { provider terbaik di Pangkalpinang kriteria Kemudahan } \\
\text { Pengguna sub kriteria Jangkauan Jaringan }\end{array}$ & 0,03 \\
\hline 12. & $\begin{array}{l}\text { Perbandingan elemen alternative level III berdasarkan } \\
\text { sasaran-kriteria-sub kriteria:pemilihan Internet service } \\
\text { provider terbaik di Pangkalpinang kriteria Kecepatan } \\
\text { transfer data sub kriteria } 115-160 \mathrm{Kbps}\end{array}$ & 0,01 \\
\hline 13. & $\begin{array}{l}\text { Perbandingan elemen alternatif level III berdasarkan } \\
\text { sasaran-kriteria-subkriteria: pemilihan Internet service } \\
\text { provider terbaik di Pangkalpinang kriteria Kecepatan } \\
\text { transfer data sub kriteria } 384-473,6 \mathrm{Kbps}\end{array}$ & 0,00 \\
\hline 14. & $\begin{array}{l}\text { Perbandingan elemen alternative level III berdasarkan } \\
\text { sasaran-kriteria-sub kriteria: pemilihan Internet service } \\
\text { provider terbaik di Pangkalpinang kriteria Kecepatan } \\
\text { transfer data sub kriteria } 384-10 \mathrm{Mbps}\end{array}$ & 0,02 \\
\hline
\end{tabular}




\begin{tabular}{|c|c|c|}
\hline 15. & $\begin{array}{l}\text { Perbandingan elemen alternatif level III berdasarkan } \\
\text { sasaran-kriteria subkriteria:pemilihan Internet service } \\
\text { provider terbaik di Pangkalpinang kriteria Kecepatan } \\
\text { transfer data sub kriteria } 7,2-14,4 \mathrm{Kbps}\end{array}$ & 0,03 \\
\hline 16. & $\begin{array}{l}\text { Perbandingan elemen alternatif level III berdasarkan } \\
\text { sasaran-kriteria sub kriteria: pemilihan Internet service } \\
\text { provider terbaik di Pangkalpinang kriteria Jenis layanan } \\
\text { sub kriteria Prabayar }\end{array}$ & 0,01 \\
\hline 17. & $\begin{array}{l}\text { Perbandingan elemen alternatif level III } \\
\text { berdasarkan sasaran-kriteria sub kriteria: pemilihan } \\
\text { Internet service provider terbaik di Pangkalpinang } \\
\text { kriteria Jenis Layanan sub kriteria Pascabayar }\end{array}$ & 0,02 \\
\hline 18. & $\begin{array}{l}\text { Perbandingan elemen alternatif level III berdasarkan } \\
\text { sasaran kriteria-sub kriteria: pemilihan Internet service } \\
\text { provider terbaik di Pangkalpinang kriteria Batasan } \\
\text { akses internet / Kuota sub kriteria Timebased }\end{array}$ & 0,03 \\
\hline 19. & $\begin{array}{l}\text { Perbandingan elemen alternative level III berdasarkan } \\
\text { sasaran-kriteria-sub kriteria:pemilihan Internet Service } \\
\text { Provider terbaik di Pangkalpinang kriteria Batasan } \\
\text { akses internet / Kuota sub kriteria Volume Based }\end{array}$ & 0,02 \\
\hline 20. & $\begin{array}{l}\text { Perbandingan elemen alternative level III berdasarkan } \\
\text { sasaran-kriteria-sub kriteria:pemilihan Internet service } \\
\text { provider terbaik di Pangkalpinang criteria Batasan } \\
\text { akses internet / Kuota sub kriteria Unlimited }\end{array}$ & 0,02 \\
\hline 21. & $\begin{array}{l}\text { Perbandingan elemen alternative level III berdasarkan } \\
\text { sasaran-kriteria-sub kriteria:pemilihan Internet service } \\
\text { provider terbaik di Pangkalpinang kriteria Tingkatan } \\
\text { jaringan sub kriteria GPRS }\end{array}$ & 0,01 \\
\hline 22 & $\begin{array}{l}\text { Perbandingan elemen alternative level III berdasarkan } \\
\text { sasaran kriteria sub kriteria pemilihan Internet service } \\
\text { provider terbaik di Pangkalpinang kriteria Tingkatan } \\
\text { jaringan sub kriteria EDGE }\end{array}$ & 0,02 \\
\hline 23. & $\begin{array}{l}\text { Perbandingan elemen alternative level III berdasarkan } \\
\text { sasaran-kriteria-sub kriteria:pemilihan Internet service } \\
\text { provider terbaik di Pangkalpinang Kriteria Tingkatan } \\
\text { Jaringan Sub Kriteria UMTS }\end{array}$ & 0,01 \\
\hline 24. & $\begin{array}{l}\text { Perbandingan alternatif level III berdasarkan } \\
\text { sasaran-kriteria-sub kriteria pemilihan Internet service } \\
\text { provider terbaik di Pangkalpinang kriteria Tingkatan } \\
\text { jaringan sub kriteria HSDPA }\end{array}$ & 0,02 \\
\hline 25 & $\begin{array}{l}\text { Perbandingan elemen alternatif level III } \\
\text { berdasarkan sasaran-kriteria-sub kriteria: pemilihan } \\
\text { Internet service provider terbaik di Pangkalpinang } \\
\text { kriteria Tingkatan jaringan sub kriteria HSPA }\end{array}$ & 0,03 \\
\hline 26. & $\begin{array}{l}\text { Perbandingan elemen alternatif level III berdasarkan } \\
\text { sasaran-kriteria-sub kriteria: pemilihan Internet service } \\
\text { provider terbaik di Pangkalpinang kriteria Jenis Kartu } \\
\text { Sub Kriteria GSM }\end{array}$ & 0,02 \\
\hline 27. & $\begin{array}{l}\text { Perbandingan elemen alternatif level III berdasarkan } \\
\text { sasaran-kriteria-sub kriteria: pemilihan Internet service } \\
\text { Provider terbaik di Pangkalpinang kriteria Jenis kartu } \\
\text { sub kriteria CDMA }\end{array}$ & 0,00 \\
\hline
\end{tabular}

inkonsistensi yang lebih kecil dari 0,1 sebagai batas maksimum nilai rasio inkonsistensi. Dengan demikian hasil perhitungan geometrik gabungan data responden cukup konsisten

\section{PENUTUP}

Berdasarkan uraian dan susunan kriteria serta alternatif yang terbentuk dengan metode Analytical Hierarchy Process (AHP), terbentuk dari 6 kriteria, 20 sub kriteria, dan 5 alternatif, Internet Service Provider terbaik di Pangkalpinang menghasilkan bahwa dari 6 Kriteria yaitu Kemudahan Pengguna, Kecepatan Transfer Data, Jenis Layanan, Batasan akses internet / Kuota, Tingkatan jaringan dan Jenis kartu. Untuk tiap - tiap kriteria tersebut menghasilkan beberapa nilai yaitu, kriteria yang paling penting adalah Kecepatan Transfer Data. Sedangkan untuk kriteria Kecepatan Transfer Data, Sub Kriteria yang paling penting adalah 7,2-14,4 Mbps. Kriteria Kemudahan Pengguna yaitu Jangkauan jarngan. Kriteria Batasan Akses Internet / Kuota yaitu Unlimited. Kriteria Tingkatan Jaringan yaitu HSPA. Kriteria Jenis Layanan yaitu Prabayar, dan untuk kriteria Jenis Kartu, Sub Kriteria yang paling penting menurut responden ahli yaitu GSM. Dan menurut responden ahli internet provider GSM yang paling penting atau yang paling banyak digunakan adalah paket internet service provider adalah XL dengan faktor terpenting yaitu kecepatan transfer data. Hasil pengolahan data dengan Expert Choice 2000 menunjukkan perbandingan berpasangan yang diberikan responden ahli memiliki nilai rasio inkonsistensi yang lebih kecil dari 0,1 sebagai batas maksimum nilai rasio inkonsistensi. Dengan demikian hasil perhitungan geometrik gabungan data responden cukup konsisten.

\section{DAFTAR PUSTAKA}

[1] Copyright Expert Choice Inc. Pittsburgh PA

[2] Hummel JM, Rossum W van, Verkerke GJ,Rakhorst G, "The Effects of Team Expert Choice on Group Decision-Making in Coolaborative New Product Development", Journal of Multi-Criteria Decision Analysis, 9(1-3):pp 90-98, 2000

[3] Ishizaka Alessio, Labib Ashraf, "Analytic Hierarchy Process and Expert Choice : Benefits and Limitations", Operational Reseach Society OR Insight Vol 22, 4, 201-220

[4] Saaty, L.Thomas, "Better World Through Better Decision Making", Proceedings of the International Symposium on the Analytic Hierarchy Process 2013.

[5] Saaty, L.Thomas, "Decision making with the analytic hierarchy process", Int.J.Services Sciences, Vol.1 No.1, 200883 Copyright @ 2008 Inderscience Interprises Ltd, University of Pittsburgh USA

[6] Turban Efraim, Aronson E.Jay, Peng Liang Ting, "Decision Support Systems and Intelligent Systems", Seventh Edition, Pearson Education Inc Prentice Hall, 2005

[7] Mulyono, “ 4 Prinsip Dasar AHP”, 2004
Dapat disimpulkan bahwa perbandingan berpasangan yang diberikan responden ahli memiliki nilai rasio 